\title{
Consumer Perspectives on the Implementation of CHSE Certification (Clean, Health, Safety, Environment Sustainability) at Fast Food Restaurants in Palembang City
}

\author{
Rebeka Ulitama S. ${ }^{1}$, Pelliyezer Karo Karo ${ }^{2 *}$, Rona Meilysa Pasaribu ${ }^{3}$, Popy \\ Vebiola $^{4}$, Netta Nopy ${ }^{5}$
}

1,2,3,4,5 Politeknik Pariwisata Palembang

*Corresponding Author.Email: pelliyezer@poltekpar-palembang.ac.id

\begin{abstract}
CHSE stands for Clean, Health, Safety, and Environmental Sustainability, which is a certification policy by the Ministry of Tourism and Creative Economy, the Republic of Indonesia, implemented to restore public confidence in the tourism sector and the creative economy in Indonesia, as a catalyst for economic growth. during the covid-19 pandemic. The CHSE program is applied to the tourism industry sub-sectors, one of which is Restaurants. This research was conducted to identify the consumer's point of view on the implementation of CHSE in Fast Food Restaurants in Palembang. The research was conducted using survey techniques and analytical descriptive analysis carried out for thirty days in six fast-food restaurants in Palembang with a total sample of 402 respondents. The results showed that during the pandemic, 86 percent of respondents still frequented restaurants where 65 percent of them belonged to the generation $\mathrm{Z}$ category and 43.8 percent of respondents still dined at restaurants. As many as 73.6 percent of respondents still think that CHSE is the same as a health protocol and there is an increase in consumer confidence of 12.8 percent that the application of CHSE in restaurants has a lower chance of infection.
\end{abstract}

Keywords: CHSE Certification, Health Protocol, Fast Food Restaurant.

\section{INTRODUCTION}

The Covid-19 pandemic is an outbreak of an infectious disease caused by a newly discovered type of coronavirus. This new virus and the disease it causes were unknown before the outbreak began in Wuhan, China, in December 2019. Covid-19 is now a pandemic occurring in many countries around the world.

The Government of the Republic of Indonesia issued the enactment of PSBB (large-scale social restrictions) rules to reduce the level of spread of Covid-19. However, the regulation still lacks clarity and does not comprehensively regulate the implementation of the New Normal (Ahmad Rosidi \& Edy Nurcahyo, 2020) ${ }^{[1]}$. Then, along with the implementation of the PSBB, the Ministry of
Health of the Republic of Indonesia decide on the health protocol for the public in public places and public facilities in the context of preventing and controlling the coronavirus disease 2019 (Covid19). From this decision, the Ministry of Health requires the public to be able to comply with the rules made through the health protocol, namely $5 \mathrm{M}$ including the implementation of health protocols including washing hands, wearing masks, maintaining distance, staying away from crowds, and reducing mobility.

Covid-19 has had a negative impact, a drastic decline in the rupiah exchange rate. The Ministry of Finance projects that the value of the rupiah will down to 20,000 per 1 USD. In terms of industry in Indonesia, 41,876 formal sector companies 
dismissed or dismissed 1,052,216 workers, and 36,298 informal sector companies dismissed or dismissed workers (Sihaloho, 2020) ${ }^{[13]}$. Layoff workers as many as 374,851 people. In addition, the decline in turnover of MSMEs and cooperatives, based on data processed by P2E LIPI, the impact of a decline in tourism on MSMEs engaged in micro food and beverage businesses reached $27 \%$. Meanwhile, the impact on small food and beverage businesses is $1.77 \%$, and medium enterprises are $0.07 \%$ (Amri, 2020) ${ }^{[2]}$. The We Love Bali program can restore Bali's economy for the better and can also help business actors, both hotels, travel businesses, restaurants, MSMEs, and others (Hanoatubun, 2020) ${ }^{[6]}$. the development of ecommerce in collaboration with digital platforms is the use of the chosen strategy because it can reduce the business gap and target market that has shifted during the Covid-19 pandemic (Karo \& Hamonangan, 2021) ${ }^{[7]}$.

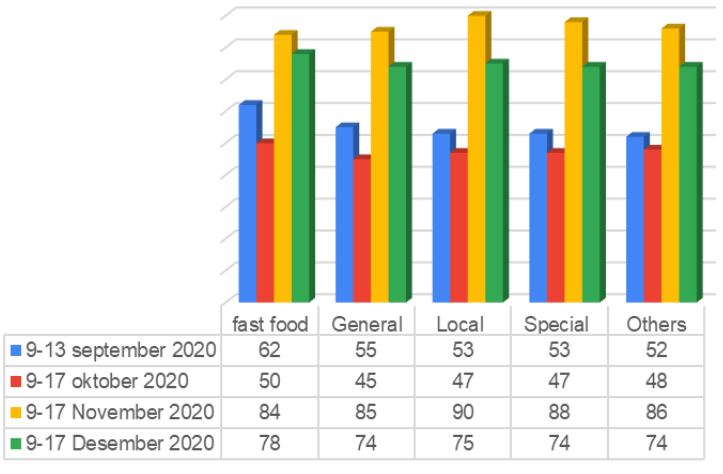

Figure 1. Percentage of public visits to restaurants (September - December 2020)

Source: Mandiri institute

Based on the institute's independent research on the percentage of public visits to restaurants, public visits to fast-food restaurants reached 62 percent of normal visits in September 2020, in this case, fast food restaurants are superior to other types of restaurants. However, in the following month, fast food restaurants fell to 50 percent. However, the percentage of visits to fast-food restaurants in november and december 2020 again rose by around 28-34 percent. The focus of this research survey is fast food or fast food restaurants in the city of Palembang that implement CHSE policies such as McDonald's, KFC, Richesse, and Burger King. Covid-19 poses a major crisis for businesses hospitality such as hotels, restaurants, and many restaurants were forced to close because lockdown policy and interaction restrictions social media in early 2020. In addition, consumers tend to avoid interactions with others in public (Kim \& Lee, 2020) ${ }^{[8]}$.

The Ministry of Tourism and Creative Economy made a new policy as an effort to rebuild tourism in the new normal era by implementing a CHSE-based health protocol (Cleanliness, Healthy, Safety, and Environmental Sustainability). The Ministry of Tourism and Creative Economy also issued guidelines for the implementation of CHSE. Guidelines for the implementation of Cleanliness, Health, Safety, and Environmental Sustainability (CHSE) in the Restaurant/Restaurants environment are operational guidelines from the decree of the Minister of Health Number HK.01.07/Menkes/ 382/2020 concerning Health Protocols for local communities. and public facilities in the context of Prevention and control of corona virus disease 2019 (Covid-19).

The application of CHSE is carried out in the hope of reducing the level of spread of covid-19, besides that there is a need for adaptation because all parties must can adapt to conditions the Covid19 pandemic, namely by continuing to improve the implementation of CHSE (Anggarini, 2021) ${ }^{[3]}$. These efforts can be carried out by business actors such as hotels, malls, and restaurants. Then added by maintaining health and hygiene. This is to restore public trust by implementing CHSE-based health protocols at their business locations so that visitors still feel safe and comfortable when leaving the house. The types of businesses that can carry out the CHSE program are as follows:

1. Tourist attraction

2. Tourist village

3. Homestay or cottage

4. Hotel

5. Restaurant

6. Meeting places, incentive trips, conventions, and exhibitions,

7. Rafting

8. Golf

9. Dive tourism business

The restaurant is one of the places that is emphasized to implement this CHSE program. Head of Restaurant Development of the Indonesian Hotel and Restaurant Association (PHRI) said that he supports the standard operation procedure (SOP) 
for restaurants facing the new normal era. A number of restaurants have re-opened dine-in services. Independent restaurants outside shopping centers and recreational areas may reopen dine-in services. The condition is that the capacity can only be 50 percent of the room capacity. The restaurant will also ask visitors to wear masks while in the restaurant area, except when they want to eat food. The restaurant also conducts temperature checks for visitors and will provide frequent hand washing advice to visitors. In addition, the condition of the room will certainly be maintained so that there is no buildup, especially in the order queue. However, there are still many people who do not care about their hand hygiene, such as not washing their hands before eating and not carrying hand sanitizer when traveling (Pinasti, 2020) ${ }^{[11]}$. Therefore, we hope that visitors can stay comfortable eating food at the restaurant even though it is shrouded in strict rules. And with the existing rules, it can restore the confidence of visitors to return to the restaurant and not be afraid to eat at the restaurant by not forgetting the CHSE-based health protocol applied in the restaurant.

\section{LITERATURE REVIEW}

\subsection{Health Protocol}

The health protocol is one of the provisions or rules that must be carried out by all parties in order to carry out activities safely during the Covid-19 pandemic. The health protocol was established by the ministry of health of the Republic of Indonesia with the aim that people can carry out activities safely and do not endanger the safety and health of others.

Prevention and control health protocol issued by the ministry of health of the Republic of Indonesia specifically through the decree of the minister of health of the Republic of Indonesia number Hk.01.07/Menkes/382/2020 concerning health protocols for the community in public places and facilities in the context of prevention and control of Corona Virus Disease 2019 (Covid-19). The health protocol has explained the rules that must be carried out by all parties who are in public places or facilities, namely:

1. Markets and the like, shopping centers or malls or shops

2. Hotels or inns or homestays or dormitories
3. Restaurant

4. Sports facilities and activities

5. Station or terminal or port or airport mode of transportation

6. Location of tourist attraction

7. Beauty or hair care services and the like

8. Creative economy services (architecture, photography, advertising, publishing, television, etc)

9. Religious activities in houses of worship

10. Event or meeting organizing services.

The rules in the health protocol at each location are intended for three parties, namely business actors, workers, and visitors or guests. Each party has its own role so that each party has adjusted the rules. In the health protocol in a restaurant, the rules for each party have been divided. The following are some of the rules that must be followed by each party, namely:

A. For Business Actors

1. Pay attention to the latest information as well as the appeals and instructions of the central government and local governments regarding Covid-19 in their area.

2. Require everyone who will enter to wash their hands with soap by running or using a hand sanitizer and providing it in every restaurant area.

3. Require workers to wear masks while working.

4. Make sure every worker understands Covid-19 and how to prevent it.

5. Prohibition for workers or visitors who have symptoms of fever, cough, runny nose, shortness of breath, and/or diarrhea or have had physical contact with people affected by Covid-19 to enter the restaurant.

6. Checking body temperature at the entrance, if a worker or visitor is found with a body temperature $>37.30 \mathrm{C}$ and checks 2 times with a distance of 5 meters, they are not allowed to enter.

B. For Workers

1. Make sure you are in good health before leaving the house, if you experience the symptoms as above, immediately check yourself to a health facility and report it to the workplace leadership.

2. Wear a mask during travel and at work. 
3. Avoid touching the mouth, face, eyes, and nose.

4. Use special clothing when working that has been provided in the workplace.

5. Immediately clean yourself before contact with family.

C. For Visitors or Consumers

1. In good health when visiting a restaurant, if you experience symptoms, stay at home or check health facilities if it continues.

2. Always use a mask when traveling and during work, keep a distance from other people, avoid touching the face area. If you have to, make sure your hands are clean or wash them thoroughly with soap and water or hand sanitizer.

3. Arriving at home, immediately clean yourself before contact with family members.

4. Clean the touched items with disinfectant liquid.

5. Consumption of balanced nutrition, 30 minutes of physical activity per day, adequate rest to increase endurance.

\subsection{CHSE in Indonesia}

The policy of the ministry of tourism and creative economy through guidelines for the implementation of hygiene, health, safety, and environmental sustainability in restaurants or restaurants July 2020 edition which is a reference for entrepreneurs or managers, employees and guests of restaurants, the provincial government, and business associations and profession related to restaurants. The guide contains, a) general guidelines and $b$ ) specific guidelines according to the restaurant or restaurant service flow that includes; a guide for employers or managers and the facilities that must be provided, a guide for guests, and a guide for employees.

The guidelines refer to the protocols set by the government of Indonesia, the World Health Organization (WHO), and the World Travel \& Tourism Council (WTIC) in the context of preventing and handling Covid-19. In the preparation of the guidelines, various parties are involved, namely restaurant or restaurant business associations, associations related to the restaurant or restaurant sector, and academics. Efforts to implement the CHSE protocol have been implemented in various sectors, especially the tourism industry, namely in tourist destinations stating $75 \%$ of the assessment of the interests and expectations of tourism destination managers for the implementation of 148 items of the CHSE protocol implementation in Kupang City (Rina Sari, $2019)^{[12]}$. This means that the assessment of the manager or owner of the tourist attraction is included in the Good criteria in the application of the cleanliness, healthy, safety, and environmental sustainable (CHSE) protocol.

\section{RESEARCH}

This type of research uses descriptive survey research methods and analytical survey methods. By using the data collected through the distribution of questionnaires to restaurant visitors. This research uses a quantitative approach. quantitative research emphasizes numerical research on phenomena. The population is visitors to fast-food restaurants in the city of Palembang. With a total of 402 respondents.

The validity and reliability tests in this instrument test were carried out on 30 respondents. By using the degrees of freedom (df) $=28$ and the significance level for the two-way test, namely alpha $(\sigma)$ of 0.05 , the results of the validity of the instrument test, it shows that each question item variable $>$ the value of $r$ table $(0.361)$, which means that each question variable item is declared valid to be used as a research questionnaire.

Reliability test using the one-shot method. The test tool that will be used for this test is the cronbach alpha coefficient. The formula used to calculate cronbach's alpha coefficient from the results of the reliability instrument test shows that both the cronbach's alpha coefficient as a whole (0.877) and each instrument exceed the minimum reliability limit used in this study, which is 0.7 . This shows that overall all instrument variables in this study are reliable (consistent).

\section{RESULT}

Respondents were divided into four characteristics. Among them are based on age, gender, occupation, domicile, and the number of visits. Based on some basic conclusions from the respondents as follows. 




Figure 2. Respondents by gender and age generation

From figure 2, respondents consist of 62 percent women and 38 percent of respondents are male. Based on their generation, male respondents are dominated by Generation $\mathrm{Z}$ as much as 24 percent. while female respondents are dominated by Generation Z, which is 52 percent.

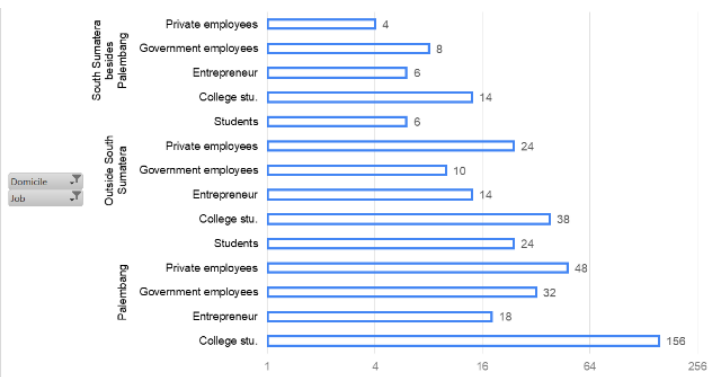

Figure 3. Respondents by domicilie and job

The respondent's data is based on their domicile and occupation. Respondents who live in Palembang as many as 69 percent. Based on domiciles in the city of Palembang, 56 percent of them are students, and respondents based on the occupation of all respondents are dominated by students as much as 51 percent.

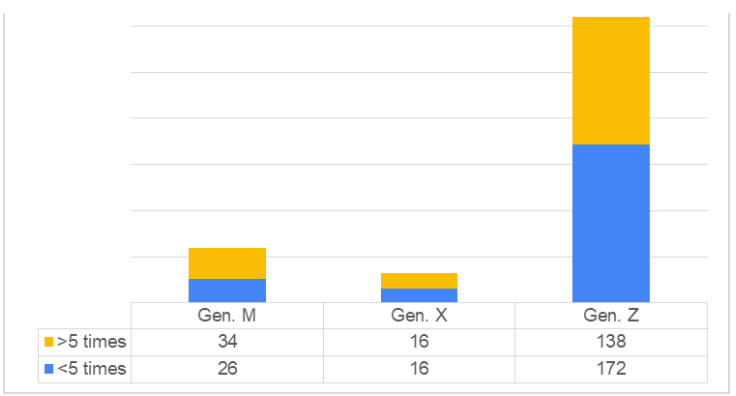

Figure 4. Visit Rate by age generation

Visits to restaurants by age generation, respondents who visited restaurants more than 5 visits were 46 percent. Based on the number of respondents who always visit restaurants,
Generation $\mathrm{Z}$ is dominated by 77 percent. This shows that there are still many respondents who visit restaurants during the pandemic starting from January with the research period starting March 1 to March 31, 2021.

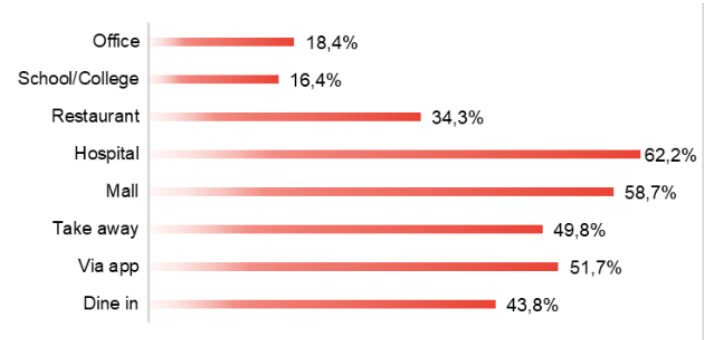

Figure 5. Covid-19 transmission location and food ordering habits

Consumers' perspectives on the location of the spread of Covid-19 occurred in hospitals by 62.2 percent. However, respondents who chose that the spread of Covid-19 occurred in restaurants were 34.3 percent. Consumers are not worried when consumers come to restaurants and eat at the place, this happens because of the habit of ordering food by respondents to eat at restaurants as much as 43.8 percent.

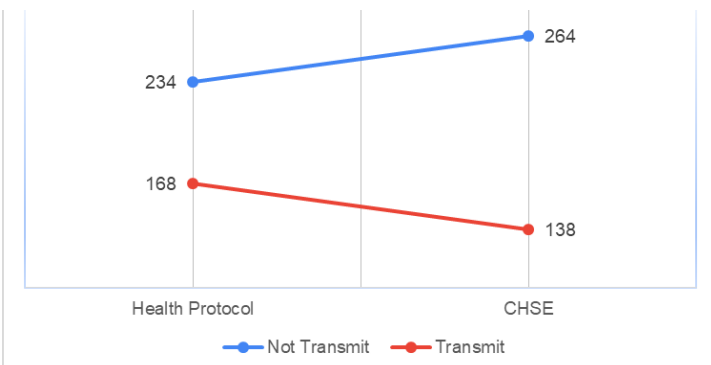

Figure 6. Health Protocol Vs CHSE based on chance of covid-19 transmission

Based on the respondents' views on the implementation of the Health Protocol and CHSE according to the chance of contracting Covid-19, 234 respondents believed that the implementation of the health protocol could not transmit Covid-19, while the implementation of CHSE was also believed to not be able to transmit Covid-19 as many as 264 respondents. From a consumer perspective, the level of consumer confidence in CHSE only increased by 12 percent from the implementation of the health protocol. This is due to the lack of information and understanding of 
consumers regarding $\mathrm{CHSE}$ and also consumers feel that there is no significant difference between CHSE and health protocols. Understanding of CHSE is very important. Homestay managers become aware of their understanding through training or discussions related to CHSE and the need for implementing CHSE during the Covid-19 pandemic for the convenience and safety of tourists who come (Palupiningtyas \& Yulianto, 2020) ${ }^{[10]}$.

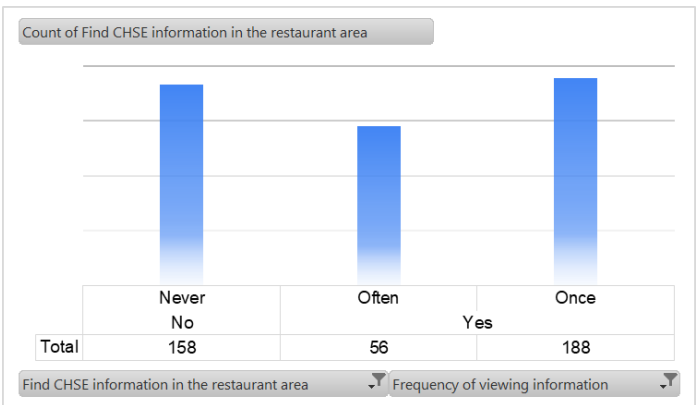

Figure 7. Find CHSE Information by Frequent rate

Due to the lack of information about CHSE, it makes consumers not aware so that when consumers choose to eat at restaurants, consumers feel safe. Information about CHSE both displayed and seen by consumers is 77 percent. From 77 percent of consumers who have seen and as many as 23 percent of consumers who often see information about the CHSE. So, it can be said that the restaurant may already have a CHSE certificate, however, the restaurant is not aware of showing the CHSE to its customers. There are problems faced by managers of the tourism industry sector, especially lodging or homestays in tourist villages during the Covid-19 pandemic regarding the implementation of CHSE who still do not understand correctly how to apply the CHSE protocol (Palupiningtyas \& Yulianto, 2020) ${ }^{[10]}$. Every manager of both tourism businesses, tourism destinations, and tourism products that already have CHSE certification must understand and implement as well as possible so that the CHSE can be implemented properly. Because this is very important. The video of the implementation of the Covid-19 health protocol at the Kyriad Hotel Airport Jakarta is expected to be used as a means of information and documentation to increase awareness of health (Febriyanto et al., 2020) ${ }^{[5]}$.

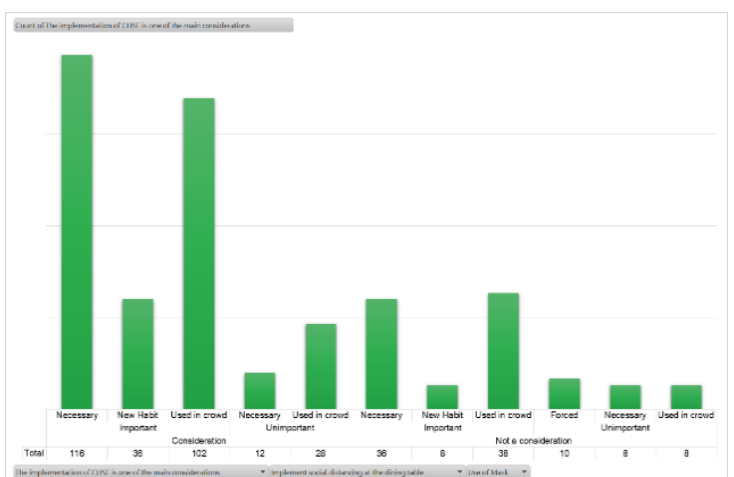

Figure 8. Implementation of CHSE, Implementation of Social Distancing, Use of Mask

Based on the consumer's perspective, as many as 254 respondents or 73 percent stated that the implementation of CHSE was one of the considerations in choosing a restaurant. As many as 10 percent of the implementation of social distancing or keeping a distance at the dining table is considered unimportant by consumers. They consider that with the existence of CHSE, the application of social distancing at the dining table no longer needs to be applied. However, some consumers think that CHSE is not a consideration but still choose social distancing or health protocols as their main consideration in choosing a restaurant and are considered important for them. The use of masks for consumers is important and as many as 9 percent of respondents stated that the use of masks is a new habit for the people of Palembang and the use of masks is used more when in a crowd as much as 25 percent so that this could potentially become a new cluster. Although CHSE is not a consideration, the use of masks for consumers is also a necessity. However, there are still consumers who feel compelled to use masks, which is as much as 2 percent. Regarding the application of CHSE to the industry in 3-star hotels in the city of Depok, from all statement indicators the lowest indicator is found in guests washing their hands with soap or hand sanitizer before and after entering the restaurant. This is due to the unavailability of a place to wash hands in the restaurant area (Ani \& Vivian Octariana, 2021) ${ }^{[4]}$. 


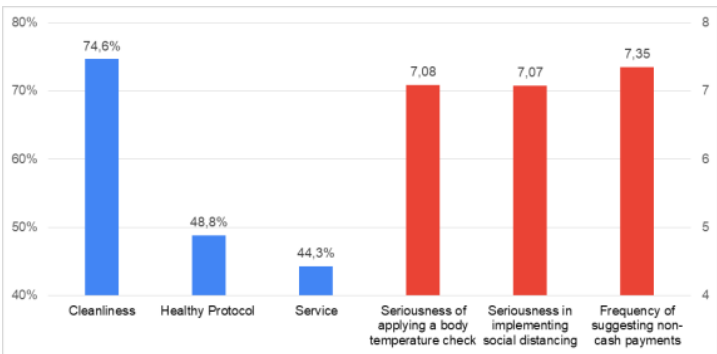

Figure 9. Three main Factors and Seriousness perspective

The main factor that is considered for consumers is cleanliness as much as 74.6 percent, this is the highest percentage and part of CHSE, namely cleanliness, health protocol as much as 48.8 percent is also part of CHSE, namely healthy, and service is 44.3 percent. The management has implemented safety and health standards in the food service system, both in terms of management and food packaging. This means that part of the CHSE that people need is cleanliness and healthy (Nurbaya et al., 2020) ${ }^{[9]}$. Food quality, price, service quality, social enjoyment, and cleanliness are factors that have a positive impact on customer satisfaction where cleanliness is the most influencing factor on customer satisfaction (Stevany et al., 2021) ${ }^{[14]}$. Meanwhile, safety and environment sustainability are not the focus for the people of palembang. Based on the consumer's perspective, in seriousness, there are still many restaurants that still provide cash or cashless payments with a value range of 7.35. There is a lack of seriousness, so it is natural that in Indonesia, especially in the city of palembang, there is still an increase in the number of positive Covid-19 spreads.



Figure 10 Observations on the implementation of CHSE
Observation of CHSE implementation based on the consumer perspective. The application of employees who always use masks is the highest presentation, which is 92.5 percent and 74.4 percent of the provision of hand sanitizers in each restaurant area and 62.7 percent of the implementation of social distancing. The implementation of other CHSE can be said to be still low, especially staff who convey information related to CHSE, suggest cashless payments, CHSE posters are clear evidence that the restaurant is still not aware of CHSE information such as stickers and advertisements. Where everything is still below the average and not in accordance with the conditions in the field based on the consumer's perspective, so this needs to be improved so that its implementation becomes more leveraged.

\section{CONCLUSION}

Here are some things that can be concluded about consumers who do not understand or are not aware of CHSE. This can be proven by several things, namely:

1. Fast food restaurant visitors still do not know more detailed information about CHSE, and are not even aware of CHSE which makes visitors still visit, and eat directly at the restaurant.

2. Visitors considered that CHSE, and health protocol were the same things, and there was no significant difference between health protocol and CHSE.

3. Based on the results of consumer observations on the implementation of CHSE carried out in restaurants, including the use of masks, social distancing, and hand sanitizers. However, these 3 factors are part of the health protocol and not part of the CHSE so that it can be said that consumers do not understand clearly about CHSE.

4. The results of the consumer's assessment of the considerations that became the main factor, namely cleanliness. This makes CHSE not a major factor but only part of CHSE, because only cleanliness is included in the CHSE part while the rest is part of the health protocol. It can be said that CHSE is not yet bound with consumers.

5. The seriousness of the CHSE implementation carried out by the restaurant is considered by 
consumers to be still in the range of 7 , which means that the restaurant implements it is only because of government regulations and not because consumer needs. Where should the seriousness in implementing CHSE in a restaurant be needed by consumers who still do not understand about CHSE.

\section{AUTHOR'S CONTRIBUTION}

Rebeka Ulitama Simanjuntak: Performed research, lead author, co-analyzed data. Pelliyezer Karo Karo: Corresponding author, analyzed data, coauthors. Popy Vebiola: Perfomed research, coauthors, research site survey. Netta Nopy: Performed research, co-authors.

\section{ACKNOWLEDGMENTS}

Special thanks to fast food restaurant in Palembang: KFC, Mc-Donald, Burger King, Richeese Factory became the research location.

\section{REFERENCES}

[1] Ahmad Rosidi, \& Edy Nurcahyo. (2020). Penerapan New Normal (Kenormalanbaru) Dalam Penanganan Covid-19 Sebagai Pandemi Dalam Hukum Positif. Ournal Ilmiah Rinjani: Media Informasi Ilmiah Universitas Gunung Rinjani, 8.2.

[2] Amri, A. (2020). Pengaruh Periklanan Melalui Media Sosial Terhadap UMKM di Indonesia di Masa PAndemi. Jurnal Brand, 2(1).

[3] Anggarini, D. T. (2021). Upaya Pemulihan Industri Pariwisata Dalam Situasi Pandemi Covid -19. Jurnal Pariwisata, 8(1). https://doi.org/10.31294/par.v8i1.9809

[4] Ani, S., \& Vivian Octariana. (2021). Efektivitas Penerapan CHSE ( Clean, Health, Safety \& Environment ) Pada Hotel Katagori Bintang 3 (Tiga) di Kota Depok. EDUTOURISM Journal Of Tourism Research, 3(01). https://doi.org/10.53050/ejtr.v3i01.159

[5] Febriyanto, E., Aisyah, E. S., \& Ningsih, I. A. (2020). VIDEO PROTOKOL KESEHATAN Covid-19 SEBAGAI KESIAPSIAGAAN MENGHADAPI NEW NORMAL PADA KYRIAD HOTEL AIRPORT JAKARTA. MAVIB Journal, 1(2). https://doi.org/10.33050/mavib.v1i2.1099

[6] Hanoatubun, S. (2020). Dampak Covid 19 terhadap Perekonomian di Indonesia. EduPsyCouns: Journal of Education, Psychology and Counseling, 2(1).

[7] Karo, P. K., \& Hamonangan, S. (2021). Analisis Strategi Pemasaran Restoran Menghadapi Masa Pandemi Covid 19 Di Kota Pagar Alam. Jurnal Sains Sosio Humaniora, 5(1). https://doi.org/10.22437/jssh.v5i1.14152

[8] Kim, J., \& Lee, J. C. (2020). Effects of Covid19 on preferences for private dining facilities in restaurants. Journal of Hospitality and Tourism Management, 45. https://doi.org/10.1016/j.jhtm.2020.07.008

[9] Nurbaya, N., Chandra, W., \& Ansar, A. (2020). Perubahan Sistem Pelayanan Makanan pada Usaha Kuliner Selama Masa Pandemi Covid19 dan Era Kebiasaan Baru di Kota Makassar. Jurnal Kesehatan Manarang, 6(Khusus). https://doi.org/10.33490/jkm.v6ikhusus.335

[10] Palupiningtyas, D., \& Yulianto, H. (2020). PENINGKATAN KEMAMPUAN PENERAPAN CHSE BAGI PENGELOLA HOMESTAY. JMM (Jurnal Masyarakat Mandiri), 5(2).

[11] Pinasti, F. D. A. (2020). Analisis Dampak Pandemi Corona Virus Terhadap Tingkat Kesadaran Masyarakat dalam Penerapan Protokol Kesehatan. Wellness And Healthy Magazine, 2(2). https://doi.org/10.30604/well.022.82000107

[12] Rina Sari, P. K. L. T. (2019). Analisis Strategi Pengembangan UKM (Studi Kasus: Usaha Restoran Bakmi Ja di Kota Padang). JOSETA: Journal of Socio-Economics on Tropical Agriculture, 1(1). https://doi.org/10.25077/joseta.v1i1.9

[13] Sihaloho, E. D. (2020). Dampak Covid-19 Terhadap Perekonomian Indonesia Dampak Covid-19 Terhadap Perekonomian Indonesia. ResearchGate, April. https://doi.org/10.13140/RG.2.2.13651.94241/ 1

[14] Stevany, K., Aditama, A. G., Rosalina, A. A., Sulistyo, F. T., Andre, V., \& Istijanto, I. (2021). Faktor-faktor yang Mempengaruhi Kepuasan dan Loyalitas Pelanggan di Restoran selama Pandemik Covid-19. JURNAL AKUNTANSI, EKONOMI Dan MANAJEMEN BISNIS, 9(1). https://doi.org/10.30871/jaemb.v9i1.2650 